\title{
Asymptomatic Bacteriuria in Pregnant Women in Jeddah, Western Region of Saudi Arabia: Call for Assessment
}

\author{
Sharifa A. Al Sibiani, $\mathrm{MB}, \mathrm{BCH}, \mathrm{CABOG}$ \\ Department of Obstetrics and Gynecology \\ Faculty of Medicine, King Abdulaziz University \\ Jeddah, Saudi Arabia \\ sharisibiani@yahoo.com
}

\begin{abstract}
To determine the prevalence and the causative organisms of asymptomatic bacteriuria among pregnant women attending their first prenatal visit at King Abdulaziz University Hospital and in a private clinic at Dr. Erfan and Bagedo Hospital, Jeddah, Saudi Arabia. A retrospective analysis was performed of the routine prenatal screening (urine culture tests) of 9,698 women attending their first prenatal clinic visit between 1 January 2004 to 31 December 2007. They were reviewed, analyzed, and correlated with data on patients' age, nationality, gravidity, and number of previous abortions. Of 9,698 women, only $166(1.7 \%)$ showed significant bacterial growth, and 1,918 patients (19.8\%) were reported as heavy mixed growth. The most common bacterium isolated was Escherichia coli on 88 patients $(53 \%)$. In this study, low prevalence of bacteriuria among pregnant women was compared to the only two available published studies conducted in the 80's in Saudi Arabia. In view of the lack of information regarding asymptomatic bacteriuria in pregnancy, and the findings of this study, the importance of a conducting a nation-wide survey to guide the revision of practice on a national scale in Saudi Arabia has increased.
\end{abstract}

Keywords: Asymptomatic bacteria, Prenatal screening, Saudi pregnant.

\section{Introduction}

Urinary tract infections (UTIs) are the most common bacterial infections during pregnancy ${ }^{[1-2]}$. The incidence of UTI varies depending on the

$\overline{\text { Correspondence } \& \text { reprint request to: }}$ Dr. Sharifa A. Al Sibiani

P.O. Box 122413, Jeddah 21332, Saudi Arabia

Accepted for publication: 16 December 2009. Received: 21 September 2009. 
local prevalence of asymptomatic bacteriuria and whether it is treatable. Asymptomatic bacteriuria (ASB) is a major risk factor for the development of urinary tract infections (UTIs) during pregnancy ${ }^{[3]}$. Thus, accounting for $70 \%$ of all cases of symptomatic UTI among unscreened pregnant women ${ }^{[3]}$. It is generally defined as true bacteriuria in the absence of specific symptoms of an acute $\mathrm{UTI}^{[4]}$. Although, the original criterion for diagnosing, it was the presence of more than 100,000 bacteria/ml on two consecutive clean catch urine samples, a more practical alternative is the detection of more than 100,000 bacterial $/ \mathrm{ml}$ in a single voided midstream urine sample ${ }^{[4,5]}$.

Furthermore, ASB occurs in $2 \%$ to $10 \%$ of all pregnancies ${ }^{[6]}$. It does not occur more frequently with pregnancy. However, it is more likely to result in a symptomatic UTI in pregnant women ${ }^{[3]}$ because of stasis of urine, and the bacteria in the urinary tract from relative obstruction, that is caused by the physiological changes during pregnancy that predispose women to bacteriuria. These physiological changes include the dilatation of the ureters secondary to progesterone, and to the mechanical obstruction from the gravid uterus later in pregnancy. Glycosuria, proteinuria, and aminoaciduria were found in pregnancy, also facilitate bacterial growth ${ }^{[3]}$.

As many as $20-40 \%$ of pregnant patients with ASB, if left untreated, will eventually develop pyelonephritis later in their pregnancy compared with $<1 \%$ of pregnant women without $\mathrm{ASB}^{[2]}$. Pyelonephritis is the most common severe bacterial infection that can lead to prenatal and maternal complications, including premature delivery, infants with low birth weight, fetal mortality, preeclampsia, pregnancy-induced hypertension, anemia, thrombocytopenia, and transient renal insufficiency $^{[1-4,7]}$.

Proper antibiotic treatment of ASB is effective in reducing the incidence of pyelonephritis and low birth weight, but there was no evidence of a reduction in preterm delivery ${ }^{[4]}$.

Screening for ASB in pregnant women has been shown to be cost effective when compared with treating UTI and pyelonephritis without screening ${ }^{[3,8-9]}$. The various screening techniques used to detect bacteriuria include urinalysis, leukocyte esterase activity, a nitrite test, and urine cultures. A midstream urine culture is still considered the best diagnostic test ${ }^{[10]}$. 
Because ASB is clinically significant in pregnancy, it should be aggressively sought, diagnosed, and treated in all stages. Screening is an essential component of prenatal care ${ }^{[10]}$. The American College of Obstetrics and Gynecology (ACOG) advocates routine screening for bacteriuria with a urine culture at the first prenatal visit and during the third trimester ${ }^{[11]}$. The US Preventive Services Task Force recommends screening for bacteriuria with urine culture for pregnant women at 12-16 weeks of gestation, hoping to identify $80 \%$ of women, who will eventually develop $\mathrm{ASB}^{[12]}$.

Using a decision analysis, screening for and treating of ASB to prevent pyelonephritis have been shown to be cost effective over a wide range of estimates. Although, the cost benefit is diminish if the rate of ASB is less than $2 \%{ }^{[8,9]}$. Estimates from mathematical modeling to evaluate the cost-effectiveness or cost-benefit of different diagnostic strategies vary significantly, with an approximate incidence rate of $9 \%$, when pyelonephritis is considered as an outcome ${ }^{[10]}$.

The low prevalence of infection in certain populations, the cost of different screening tests, and the uncertainty about the benefits of treatment in decreasing adverse outcomes of pregnancy have, however, been used to argue against universal screening and treatment ${ }^{[4]}$.

In Saudi Arabia, there is insufficient old data and no recent data about the prevalence of bacteriuria (asymptomatic or symptomatic) during pregnancy. While there are no new data to indicate that women should not be screened for ASB, it is difficult to estimate accurately the cost-effectiveness of screening it without up-to-date information on the prevalence.

The primary purpose of this study is to determine the prevalence and the causative organisms of ASB among pregnant women attending their first prenatal visit at two hospitals in Jeddah, Western region of Saudi Arabia. Secondly, the purpose is to evaluate the value of the current policy of universal screening of pregnant women among our local population.

\section{Patients and Methods}

This is a retrospective descriptive cross-sectional hospital-based study (prevalence study) where the results of the routine prenatal 
screening urine culture tests of 9,698 women attending first prenatal clinic from 1 January 2004 to 31 December 2007. They were reviewed based on their age, nationality, gravidity, and history of abortions. The data was obtained from two hospitals; King Abdulaziz University Hospital (KAUH) which is a teaching hospital, and a private clinic in a private hospital, both in Jeddah, the Western region of Saudi Arabia. KAUH is the main teaching hospital of the Western region, with a total of 4,000-4,500 deliveries per year. The private clinic has an average of 100-150 pregnant women attending per month. Both are providing tertiary medical care for the regional population of Western Saudi Arabia.

The screened women were divided into groups according to their nationality: Saudi and Non Saudi, age: $<20$ years, $20-34$ years, $>35-44$ years and $>45$ years), gravidity: nulliparous/primigravida (G1), multiparous (G2-G5), and grandmultiparous ( $>$ G5). In addition to history of previous abortion: Women with and without history of abortion.

A quantitative urine culture was obtained with blood and MacConkey agar plate. Significant growth means; the presence of $>$ 100,000 organisms $/ \mathrm{ml}$ urine of a single bacterium, while heavy mixed growth means; presence of $>100,000$ organisms $/ \mathrm{ml}$ urine of more than one type of bacteria.

\section{Data Analysis}

Statistical analyses were performed using the Statistical Package for the Social Science (SPSS), Version 16 for Windows. Continuous variables were summarized using descriptive statistics in terms of means \pm standard deviations; 95\% confidence intervals (95\% CI), minimums and maximums, while a Chi-square test was used to compare categorical variables. A p-value less than 0.05 were considered significant.

\section{Results}

\section{Demographics of Study Population}

A total of 9,698 pregnant women $6,082(62.7 \%)$ were Saudi, aged between 15 and 48 years; mean, $27.6(95 \% \mathrm{CI}=27.52-27.76)$. Their gravidity ranged was between $1-17$; mean $3.53(95 \% \mathrm{CI}=3.48-3.58)$. 
Their parity was between $0-14$; mean $2.07(95 \% \mathrm{CI}=2.03-2.12)$. Their history of abortions ranged was from $0-11$; mean $0.48(95 \% \mathrm{CI}=0.46-$ $0.5)$ and were screened for bacteriuria by mid stream urine culture.

\section{Prevalence of Urine Culture Results and Demographic}

Of the 9,698 culture results, 7,614 $(78.5 \%, 95 \% \mathrm{CI}=77.7-79 \%)$ yielded no growth; $1,918(19.8 \%, 95 \% \mathrm{CI}=19-20.6 \%)$ yielded heavy mixed/mixed growth, and only $166(1.7 \%, 95 \% \mathrm{CI}=1.45-1.97 \%)$ showed significant growth.

Figure 1 shows the most common bacterium isolated was Escherichia coli (E. coli), 88 (53\%). Other bacteria included Candida albicans, 33 (19.9\%); Group B Streptococcus (GBS), 18 (10.8\%), Staphylococcus, 8 (4.8\%); Actinobacter, 8 (4.8\%); Diphtheroids, 5 (3\%), Proteus, 1 (0.6\%); and Klebsiella $1(0.6 \%)$ species,

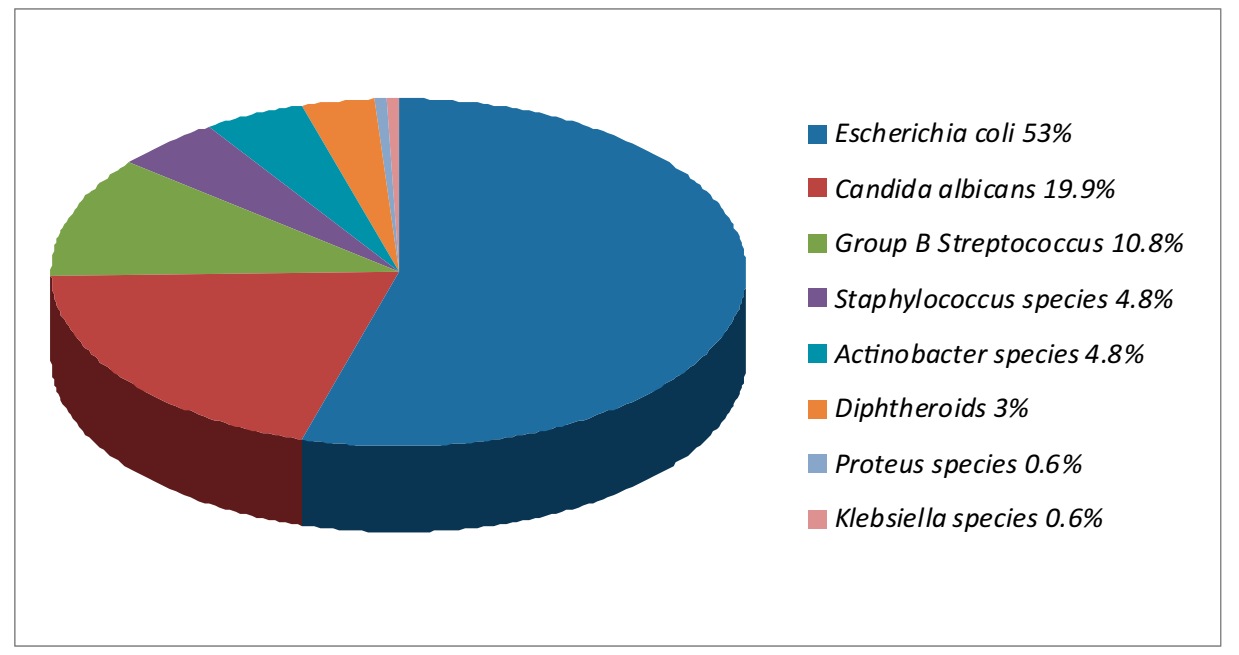

Fig. 1. Percent of isolated pathogens.

Table 1 shows that nationality had significant relationship with the significant growth urine result $\left(\chi^{2} ; 32.19 ; \mathrm{df}, 2, \mathrm{p}=0.0005\right)$. Most of the significant growth was among Saudi nationality group, $139(2.3 \%)$

Age groups had considerable relationship with the significant growth urine culture result $\left(\chi^{2} ; 48.8 ; \mathrm{df}, 6, \mathrm{p}=0.0005\right)$. Most of the significant growth occurred in the 35-45 age group; 43 (2.8\%), followed 
by age group $20-34$ years; $123(1.7 \%)$. There was no significant growth among age group $<20$ years and $>45$ years.

Gravidity/Parity groups also had considerable relationship with the significant growth urine result $\left(\chi^{2} ; 35.17 ; \mathrm{df}, 6, \mathrm{p}=0.0005\right)$. Most of the

Table 1. Summary of 9,698 urine culture results and patient demographic characteristics.

\begin{tabular}{|c|c|c|c|c|c|}
\hline $\begin{array}{l}\text { Characteristics / } \\
\text { Urine results }\end{array}$ & $\begin{array}{c}\text { NO Growth N } \\
(\%)\end{array}$ & $\begin{array}{c}\text { Mixed } \\
\text { Growth N (\%) }\end{array}$ & $\begin{array}{l}\text { Significant } \\
\text { Growth N } \\
(\%)\end{array}$ & Total N (\%) & $\begin{array}{l}\chi-^{2}(P- \\
\text { value })\end{array}$ \\
\hline N (\%) & $7614(78.5 \%)$ & $1918(19.8 \%)$ & $166(1.7 \%)$ & $9698(100 \%)$ & \\
\hline $\begin{array}{l}\text { NATIONALITY } \\
\text { Saudi } \\
\text { Non Saudi } \\
\text { Total }\end{array}$ & $\begin{array}{c}4737(77.9) \\
2876(79.6 \%) \\
7613(78.5 \%)\end{array}$ & $\begin{array}{c}1206(19.8 \%) \\
711(19.7 \%) \\
1917(19.8 \%)\end{array}$ & $\begin{array}{c}139(2.3 \%) \\
27(0.7 \%) \\
166(1.7 \%)\end{array}$ & $\begin{array}{l}6082(100 \%) \\
3614(100 \%) \\
9696(100 \%)\end{array}$ & $\begin{array}{l}32.19^{a}, \\
(0.0005)\end{array}$ \\
\hline $\begin{array}{c}\text { AGE }(\text { years }) \\
<20 \\
20-34 \\
35-45 \\
>45 \\
\text { Total }\end{array}$ & $\begin{array}{c}531(76.2 \%) \\
5809(78.1 \%) \\
1227(81.0 \%) \\
47(94.0 \%) \\
7614(78.8 \%)\end{array}$ & $\begin{array}{c}166(23.8 \%) \\
1504(20.2 \%) \\
245(16.2 \%) \\
3(6.0 \%) \\
1918(19.9 \%)\end{array}$ & $\begin{array}{c}0(0.0 \%) \\
123(1.7 \%) \\
43(2.8 \%) \\
0(0.0 \%) \\
166(1.7 \%)\end{array}$ & $\begin{array}{c}697(100 \%) \\
7436(100 \%) \\
1515(100 \%) \\
50(100 \%) \\
9698(100 \%)\end{array}$ & $\begin{array}{l}48.8^{\mathbf{b}} \\
(0.0005)\end{array}$ \\
\hline $\begin{array}{l}\text { GRAVIDITY } \\
\text { G1 } \\
\text { G2-G5 } \\
>\text { G5 } \\
\text { Total }\end{array}$ & $\begin{array}{l}2018(77.6 \%) \\
3970(77.6 \%) \\
1620(81.9 \%) \\
7614(78.8 \%)\end{array}$ & $\begin{array}{c}557(21.4 \%) \\
1032(20.2 \%) \\
327(16.5 \%) \\
1918(19.9 \%)\end{array}$ & $\begin{array}{c}24(0.9 \%) \\
112(2.2 \%) \\
30(1.5 \%) \\
166(1.7 \%)\end{array}$ & $\begin{array}{l}2599(100 \%) \\
5114(100 \%) \\
1977(100 \%) \\
9698(100 \%)\end{array}$ & $\begin{array}{l}35.2^{\mathbf{c}}, \\
(0.0005)\end{array}$ \\
\hline $\begin{array}{l}\text { Hx of previous } \\
\text { abortions } \\
\text { NO } \\
\text { YES } \\
\text { Missed } \\
\text { Total }\end{array}$ & $\begin{array}{c}5362(78.4 \%) \\
2235(78.7 \%) \\
17 \\
7597(78.3 \%)\end{array}$ & $\begin{array}{c}1354(19.8 \%) \\
558(19.7 \%) \\
6 \\
1918(19.9 \%)\end{array}$ & $\begin{array}{c}120(1.8 \%) \\
46(1.6 \%) \\
0 \\
166(1.7 \%)\end{array}$ & $\begin{array}{c}6836(100 \%) \\
2839(100 \%) \\
23 \\
9698(100 \%)\end{array}$ & $\begin{array}{l}0.258^{d} \\
(0.879)\end{array}$ \\
\hline
\end{tabular}

${ }^{\mathrm{a}} \mathrm{df}, 2 ;{ }^{\mathrm{b}} \mathrm{df}, 6 ;{ }^{\mathrm{c}} \mathrm{df}, 6 ;{ }^{\mathrm{d}} \mathrm{df}, 2$

Abbreviations: $\chi^{2=}$ Chi-square test; G1 = primigravida/nulliparous, G2-G5 = multiparous, $>$ G5 = grandmultiparous.

significant growth was observed in the multiparous (G2-G5) group, 112 $(2.2 \%)$, followed by grandmultiparous (> G5); $30(1.5 \%)$. The primigravida/nulliparous group showed significant growth only in 24 women $(0.9 \%)$. History of previous abortion had no relationship with the urine culture result $\left(\chi^{2} ; 0.258 ; \mathrm{df}, 2, \mathrm{p}=0.879\right)$.

The results of this study showed that the most significant growth was found among Saudi women, in 35-45 years age group and in the multiparous (G2-G5) group.

\section{Discussion}

ASB occurs in $2-10 \%$ of all pregnancies ${ }^{[6]}$. The majority of the most recent studies ${ }^{[13-24]}$, including observational studies from developing 
countries, found the prevalence ranged between $4-10 \%$. This range during pregnancy was reported to be as high as $78.7 \%$ in a population from Nigeria that included Staphylococcus aureus as an uropathogen ${ }^{[25]}$.

This variation in studies can be attributed to several factors such as the geographical variation, socio-economic status, ethnicity of the subjects, setting of the study (primary care, community based, or hospitals), and the variation in the screening tests (urine dipstick, microscopy, and culture).

Race-specific rates show significant variation, as well as there is variation within same race living in different geographical areas or with socio-economic status. Reported prevalence of ASB among Bangladeshi pregnant women living in London was $2.0 \%$ and $12 \%$ in rural areas in Bangladesh ${ }^{[22,26]}$. Thus, it is important to evaluate the prevalence of ASB in a specific population.

This study reported that the prevalence of ASB among pregnant women attending their first prenatal visit in two tertiary centers in Jeddah, Western region of Saudi Arabia was 1.7\% (95\% CI: 1.45$1.97 \%$ ). This rate is much lower than the previously reported from Saudi Arabia; $14.2 \%$ bacteriuria in pregnant women from the eastern region (in 1989), where only $25 \%$ of the women were symptomatic (i.e., the prevalence of ASB was 10.5\%). 15.8\% bacteriuria was reported in 1991 from the Western region, where the ASB was $7.1 \%^{[27-28]}$. Furthermore, our prevalence rate was much lower than the recent reports from other Middle Eastern countries.

In Table 2, for example, the reported prevalence of ASB is $30 \%$, $9.9 \%, 3.3-6.1 \%$ and $4.8 \%$ among pregnant women in Yemen ${ }^{[18]}$, Qatar $^{[23]}$, Iran ${ }^{[21,24]}$ and United Arab Emirates (UAE) ${ }^{[17]}$, respectively. However, the prevalence in this study was the same as what has been reported in Malaysian pregnant women $(1.9 \%)^{[14]}$ and Bangladeshi women $(2 \%)$ living in London ${ }^{[26]}$. The explanation for low prevalence compared to the previous local studies could have been due to the improved socio-economic status. Particularly, in the study that was reported from the Eastern region where bacteriuria was significantly more common among the low socio-economic group. The higher prevalence was in Qatar, Iran, and UAE; perhaps it's because their patients were recruited from primary heath care centers while ours from tertiary centers. 
Table 2. Summary of reported prevalence of ASB in pregnant women and percentage (\%) of $E$. coli isolated from some countries.

\begin{tabular}{|c|c|c|}
\hline COUNTRY & Prevalence (\%) & $E . \operatorname{coli}(\%)$ \\
\hline \multicolumn{3}{|l|}{ Middle East } \\
\hline Saudi Arabia & & \\
\hline Eastern region (Al-Sibai et al., 1989) ${ }^{[27]}$ & $10.5 \%$ & - \\
\hline Western region (Abduljabber et al., 1991) ${ }^{[28\}}$ & $7.1 \%$ & $89 \%$ \\
\hline Yemen (Al-Haddad, 2005) ${ }^{[18]}$ & $30 \%$ & $41.5 \%$ \\
\hline Qatar (Aseel et al., 2009) & $9.9 \%$ & $31 \%$ \\
\hline $\begin{array}{l}\text { Iran } \\
\text { (Hazhir, 2007) })^{[21]} \\
\text { (Moghadas and Irajian, 2009) })^{[24]}\end{array}$ & $\begin{array}{l}6.1 \% \\
3.3 \%\end{array}$ & $\begin{array}{c}- \\
70 \%\end{array}$ \\
\hline $\begin{array}{l}\text { United Arab Emirates } \\
\text { (Abdullah and Al Moslih, 2005) })^{[17]}\end{array}$ & $4.8 \%$ & $66.7 \%$ \\
\hline \multicolumn{3}{|l|}{ Asia } \\
\hline Bangladesh (Ullah et al., 2007) ${ }^{[22]}$ & $12 \%$ & $75.9 \%$ \\
\hline Pakistan (Fatima and Ishrat, 2006) ${ }^{[19]}$ & $9.9 \%$ & $78.6 \%$ \\
\hline Malaysia (Mohammad et al., 2002) ${ }^{[14]}$ & $1.9 \%$ & $40 \%$ \\
\hline \multicolumn{3}{|l|}{ Africa } \\
\hline Nigeria (Akinolye et al., 2006) ${ }^{[20]}$ & $21.0 \%$. & $11.1 \%$ \\
\hline Nigeria (Amadi et al., 2007) ${ }^{[25]}$ & $78.7 \%$ & $25.4 \%$ \\
\hline \multicolumn{3}{|l|}{ Europe } \\
\hline Turkey (Tugrul et al., 2005) ${ }^{[16]}$ & $8.1 \%$. & $77.77 \%$ \\
\hline
\end{tabular}

E. coli has been identified as the most common pathogen isolated among the pregnant women in this study (Fig. 1), which was consistent with the majority of the reported studies in literature ${ }^{[13-19,22-24,27,28]}$. However, E. coli formed 53\% of the isolated organisms, which is lower than what have been reported in countries (Table 2) such as Pakistan, $2006(78.6 \%)^{[19]}$; Turkey, $2005(77 \%)^{[16]}$; Iran, $2009(70 \%)^{[24]}$ and in UAE, $2005(66.7 \%)^{[17]}$. Moreover, higher than Qatar, $2009(31 \%)^{[12]}$; Malaysia, $2002(40 \%)^{[3]}$; Yemen $2005(41.5 \%)^{[7]}$; and Nigeria, 2006 $(11.1 \%)^{[20]}$.

E. coli is the most common microorganism in the vaginal and rectal area. Because of the anatomical and the functional changes that occur during pregnancy, the risk of acquiring UTI from E. coli is high ${ }^{[14]}$.

The presence of Candida albicans in this present study $(19.9 \%)$ is higher than other studies ${ }^{[14,20]}$ : Nigeria, $2006(7.9 \%)$ and Malaysia (2 out of 32 cultures; $6.25 \%$ ). The physiological alterations during pregnancy that affects immunity and high prevalence of diabetes, including gestational diabetes, among our population may account for this high prevalence of C. albicans. GBS, which is occasionally isolated in urine $(10 \%)^{[29]}$ had a prevalence of $10.8 \%$ in this study, less than that reported 
from Malaysia (15\%). GBS bacteriuria may be associated with preterm rupture of membranes, premature delivery, and early onset neonatal sepsis. Thus, all pregnant women with these bacteria during gestation should receive treatment at the time of diagnosis, as well as intrapartum antibiotic prophylaxis ${ }^{[2,30]}$.

The $19.9 \%$ of mixed bacterial growth reported in this study was similar to that reported from Malaysia $(17.2 \%)^{[14]}$ and less than $25.5 \%$ reported by Amadi et al. from Nigeria ${ }^{[25]}$. It likely indicates that contamination of urine specimens still happens, despite the strict instructions given to patients about the collection of a midstream urine specimen. Proper collection, appropriate transport, and the early processing of urine specimens remain essential.

During pregnancy, bacteriuria/UTIs are more common in women who are older and of higher parity ${ }^{[7,31]}$. However, closer scrutiny of the published literature reveals that the age and parity effects are poorly characterized. For example, some studies showed that the prevalence of ASB increased with age $e^{[16,20]}$, while others found it more with a younger age group ${ }^{[21,23,24,27]}$. This study showed the age groups had a significant relationship with the urine culture result, and there was no positive growth among age group $<20$ years and $>45$ years. This observation among these groups was similar to recent data from $\operatorname{Iran}^{[20]}$. Nevertheless, in contrast to previously published local data by Al-Sibai et $a l .{ }^{[27]}$, when bacteriuria was more common $(23.2 \%)$ among women below the age of 20 years. The reason for this observation was not obvious.

With regard to gravidity/parity, some previous studies found that the prevalence of ASB was highly associated with multiparity ${ }^{[16,20]}$. In the present study, gravidity had a significant relationship with urine culture results, and primigravida (nulliparous) women had lower rate of bacteriuria than those who had babies. This rate was consistent with previously published local data ${ }^{[27]}$, however, in 1989 , the rate of ASB among primigravida/nulliparous women was 10 times $(9.6 \%)$ more than our current rate $(0.9 \%)$. Multiparous groups (G2 - G5) in present study had higher bacteriuria than nulliparous/ primigravida, and grand multiparous women ( $>$ G5). Though, no meaningful trends were observed with increasing parity. 
Versi and colleagues (1997) ${ }^{[26]}$ found grand multiparous white women had a higher bacteriuria rate than white women of lower parity. This trend with parity was not observed in the Bangladeshi women. He hypothesized that the effect of parity was not global, but rather dependent on race and/or geography. This hypothesis was not true as even in the same ethnic group the pattern of the prevalence of bacteriuria with age and parity was not consistent over time. For example, studies on Nigerian women ${ }^{[20,32]}$ showed higher bacteriuria rates among nulliparous women in 1993. A 2006 study confirmed it was higher in multiparous women, and that the multiparity was associated with increased bacteriuria in pregnancy.

In conclusion, the result of this study updates information on the prevalence of ASB among pregnant women. Plus, attending their first prenatal visit in two tertiary centers in Jeddah, Saudi Arabia was low $(1.7 \%)$, and the predominant organism of E. coli was $53 \%$. A large scale national study that includes primary health care centers should be conducted to determine the actual prevalence of ASB in the obstetric population in Saudi Arabia, and to identify the group that is vulnerable for developing a UTI. If low prevalence is confirmed at the national level and vulnerable groups are identified, it is more cost effective to recommend selective rather than universal screening for ASB in pregnancy. Predominantly, because the cost benefit of screening for, and the treatment of ASB, to prevent pyelonephritis, have shown to be diminished if the rate of ASB is less than $2 \%$. However, the uncertainty of the benefits of treatment in decreasing adverse outcomes of pregnancy is not clear. To the best of author knowledge this the only recent paper reporting prevalence of ASB among pregnant women in Saudi Arabia.

\section{References}

[1] Cunningham FG, Lucas MJ. Urinary tract infections complicating pregnancy. Baillieres Clin Obstet Gynaecol 1994; 8(2): 353-373.

[2] Le J, Briggs GG, McKeown A, Bustillo G. Urinary tract infections during pregnancy. Ann Pharmacother 2004; 38(10): 1692-701.

[3] Jones LA, Woodman PJ, Ruiz HE, Urinary tract infections in pregnancy. eMedicine 9 December 2009. 9 December $2009<$ http://emedicine.medscape.com/article/452604overview>.

[4] Smaill F, Vazquez JC. Antibiotics for asymptomatic bacteriuria in pregnancy. Cochrane Database Syst Rev 2007; 18(2): CD000490. 
[5] Kass EH. The role of asymptomatic bacteriuria in the pathogenesis of pyelonephritis. In: Quinn EL, Kass EH, (eds.) Biology of Pyelonephritis. Boston: Little Brown Co, 1960. 399412.

[6] Whalley P. Bacteriuria of pregnancy. Am J Obstet Gynecol 1967; 97(5): 723-738.

[7] Foxman B. Epidemiology of urinary tract infections: incidence, morbidity, and economic costs. Am J Med 2002; 113(Suppl 1A): 5S-13S.

[8] Rouse DJ, Andrews WW, Goldenberg RL, Owen J. Screening and treatment of asymptomatic bacteriuria of pregnancy to prevent pyelonephritis: a cost-effectiveness and cost-benefit analysis. Obstet Gynecol 1995; 86(1): 119-123.

[9] Wadland WC, Plante DA. Screening for asymptomatic bacteriuria in pregnancy. A decision and cost analysis. J Fam Pract 1989; 29(4): 372-376.

[10] Tolosa JE. Antibiotics for Asymptomatic Bacteriuria in Pregnancy: RHL commentary (last revised: 14 January 2008). The WHO Reproductive Health Library; Geneva: World Health Organization.

[11] ACOG. Antimicrobial therapy for obstetric patients. ACOG Educational Bulletin, Washington, DC: American College of Obstetricians and Gynecologists, 1998; 245: 8-10.

[12] US Preventive Services Task Force. Guide to Clinical Preventive Services, 2007: Recommendations of the U.S. Preventive Services Task Force. Section Recommendations for Adults, Infectious Diseases.

$<$ http://www.ncbi.nlm.nih.gov/bookshelf/br.fcgi?book=hscps2007\&part=A50081>

[13] McNair RD, MacDonald SR, Dooley SL, Peterson LR. Evaluation of the centrifuged and Gram-stained smear, urinalysis, and reagent strip testing to detect asymptomatic bacteriuria in obstetric patients. Am J Obstet Gynecol 2000; 182(5): 1076-1079.

[14] Mohammad M, Mahdy ZA, Omar J, Maan N, Jamil MA. Laboratory aspects of asymptomatic bacteriuria in pregnancy. Southeast Asian J Trop Med Public Health 2002; 33(3): $575-580$.

[15] McIsaac W, Carroll JC, Biringer A, Bernstein P, Lyons E, Low DE, et al. Screening for asymptomatic bacteriuria in pregnancy. J Obstet Gynaecol Can 2005; 27(1): 20-24.

[16] Tugrul S, Oral O, Kumru P, Kose D, Alkan A, Yildirim G. Evaluation and importance of asymptomatic bacteriuria in pregnancy. Clin Exp Obstet Gynecol 2005; 32(4): 237-240.

[17] Abdullah AA, Al-Moslih MI. Prevalence of asymptomatic bacteruria in pregnant women in Sharjah, United Arab Emirates. East Mediterr Health $J$ 2005; 11(5-6): 1045-1052.

[18] Al-Haddad AM. Urinary tract infection among pregnant women in Al-Mukalla district, Yemen. East Mediterr Health J 2005; 11(3): 505-510.

[19] Fatima N, Ishrat S. Frequency and risk factors of asymptomatic bacteriuria during pregnancy. J Coll Physicians Surg Pak 2006; 16(4): 273-275.

[20] Akinloye O, Ogbolu DO, Akinloye OM, Terry Alli OA. Asymptomatic bacteriuria of pregnancy in Ibadan, Nigeria: a re-assessment. Br J Biomed Sci 2006; 63(3): 109-112.

[21] Hazhir S. Asymptomatic bacteriuria in pregnant women. Urol J 2007; 4(1): 24-27.

[22] Ullah MA, Barman A, Siddique MA, Haque AK. Prevalence of asymptomatic bacteriuria and its consequences in pregnancy in a rural community of Bangladesh. Bangladesh Med Res Counc Bull 2007; 33(2): 60-64.

[23] Aseel M, Al-Meer F, Al-Kuwari, Ismail M. Prevalence and predictors of asymptomatic bacteriuria among pregnant women attending primary health care in Qatar. Middle East $J$ Fam Med 2009; 7(4): 10-13. 
[24] Moghadas AJ, Irajian G. Asymptomatic urinary tract infection in pregnant women. Iran J Pathol 2009; 4(3): 105-108.

[25] Amadi ES, Enemuo OB, Nwosu OK, Onyeagba RA, Ugbogu OC. Asymptomatic bacteriuria among pregnant women in Nigeria. J Med Sci 2007; 7(4): 698-700.

[26] Versi E, Chia P, Griffiths DJ, Harlow BL. Bacteriuria in pregnancy: a comparison of Bangladeshi and Caucasian women. Int Urogynecol J Pelvic Floor Dysfunct 1997; 8(1): 8-12.

[27] Al-Sibai MH, Saha A, Rasheed P. Socio-biological correlates of bacteriuria in Saudi pregnant women. Public Health 1989; 1103(2): 113-121.

[28] Abduljabbar H, Moumena RA, Mosli HA, Khan AS, Warda A. Urinary tract infection in pregnancy. Ann Saudi Med 1991; 11(3): 322-324.

[29] Kennedy E. Pregnancy, urinary tract infections. eMedicine $<\mathrm{http} / / / \mathrm{www}$.emedicine.com/emerg/topic485.htm>(accessed 10 October 2005).

[30] Smaill F. Intrapartum antibiotics for group B streptococcal colonization. Cochrane Database Syst Rev 2010; 20(1): CD000115

[31] Dwyer PL, O'Reilly M. Recurrent urinary tract infection in the female. Curr Opin Obstet Gynecol 2002; 5(14): 537-543.

[32] Olusanya O, Ogunledun A, Fakoya TA. Asymptomatic significant bacteriuria among pregnant and non-pregnant women in Sagamu, Nigeria. West Africa J Med 1993; 12(1): 27-33. 
البولية الجرثومية اللأَّر اضية بين النساء الحو امل في جدة ، المنطقة الغربية من المملكة العربية السعودية: دعوة للتقييم

\section{شريفة علي الصبياني}

قسم النساء والولادة ، كلية الطب ، جامعة الملك عبد العزيز جدة - المدلكة العربية السعودية

المستخلص. هذه دراسة لتحديد مدى انتـثنار البوليــة الجرثوميــة

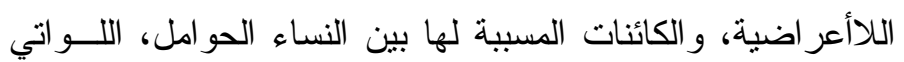

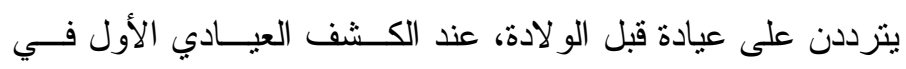

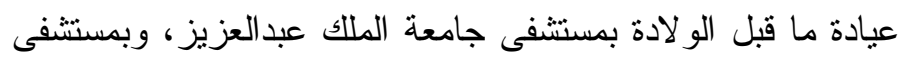

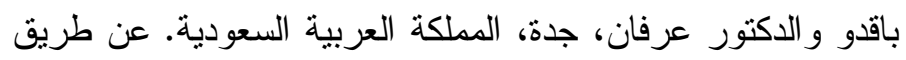

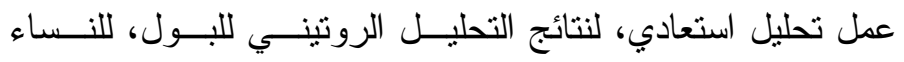

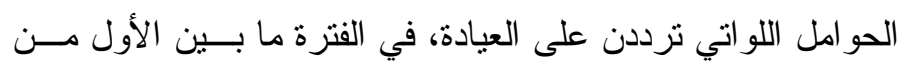

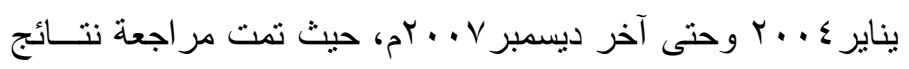

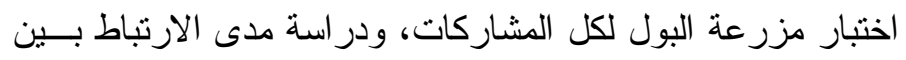

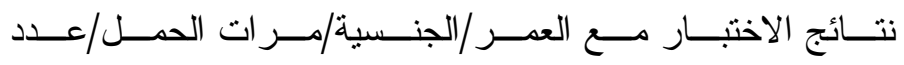

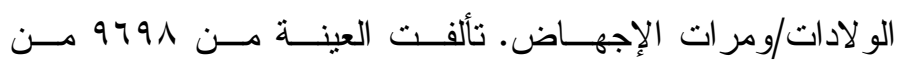

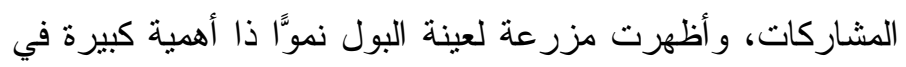

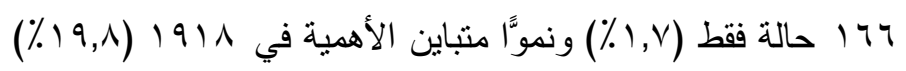

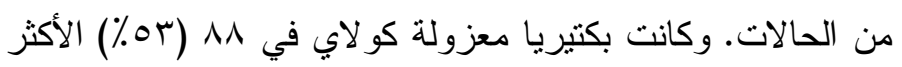

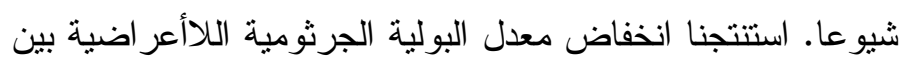

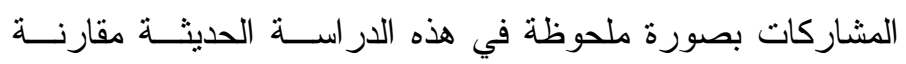

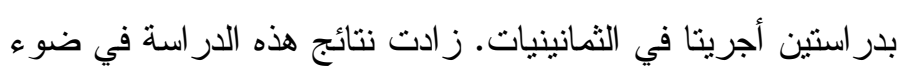


القصور الحاد في الأبحاث في هذا الموضوع، من أهميــة عـــل

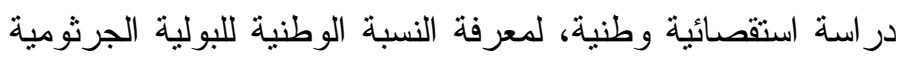

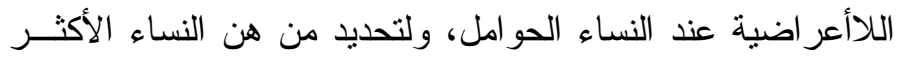

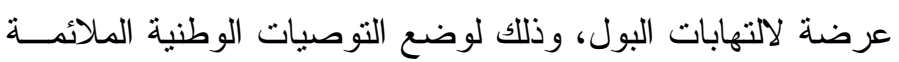

